\title{
Size matters: the effects of forest fragmentation and resource availability on the endemic Sumba Hornbill Aceros everetti
}

\author{
ARNOLD F. SITOMPUL, MARGARET F. KINNAIRD and \\ TIMOTHY G. O'BRIEN
}

\section{Summary}

We examined the influence of forest fragmentation and resource availability on the abundance and distribution of Sumba Hornbill Aceros everetti, a large, canopy-dwelling bird endemic to Sumba Island, Indonesia. Hornbill numbers were estimated monthly from August 1998 to September 1999. Estimates were made in three large ( $\geq 1,000$ ha) and three small ( $<1,000$ ha) forest fragments, using a standard line transect method. Phenological patterns of canopy trees were assessed in $10 \times 50 \mathrm{~m}$ plots. Our data indicated that forest patch size may be a better predictor of Sumba Hornbill abundance and distribution than overall resource availability. Hornbills occurred at higher densities in large forests $\left(6 / \mathrm{km}^{2}\right)$ than small forests $\left(2.4 / \mathrm{km}^{2}\right)$. Small forests produced more fruit/ha per month but lacked a number of important hornbill food species. Monthly fruit availability in large and small forest fragments had no significant effect on fluctuations in hornbill density. However, hornbill densities were significantly higher in forests with high densities of strangling figs, after controlling for patch size, and in larger forests hornbill densities correlated with the abundance of ripe figs. We hypothesize that small patches still have conservation value if they are within hornbill ranging distance, and speculate that Sumba's forests are in a dynamic phase before the full impact of fragmentation has been expressed.

\section{Introduction}

Fragmentation is one of the most common results of habitat disturbance in forest ecosystems (Harris 1984, Pickett and White 1985, Laurance and Bierregaard 1997, Wilcove et al. 1986) and has been shown to have a wide variety of effects on plant and animal assemblages across taxonomic levels. The most obvious effects of fragmentation and accompanying habitat loss are changes in diversity resulting from species loss (Newmark 1987, Laurance 1989, Malcolm 1994, Restrepo et al. 1997, Sieving and Karr 1997, Karr 1982, Brown and Hutchings 1997, Klein 1989) and changes in relative abundance (Lynam 1997, Rylands and Keuroghlian 1988, Decker and Kinnaird 1992, Menon and Poirier 1996, Tocher et al. 1997, Terborgh 1990, Robinson 1998). Less obvious effects include changes in ecological processes such as germination and recruitment (Laurance et al. 1998, Malvido 1998, Turner et al. 1996, Trillium ovatum: Jules 1998, Heliconia acuminata: Bruna 1999), mortality (Robinson 1998, Sieving and Karr 1997, Wong et al. 1998, Wilcove 1985, Terborgh and Winter 1980) and reproduction (Gibbs and Faaborg 
1990, Burke and Nol 1998). These changes have profound implications for population viability and long-term persistence of plants and animals (Soulé and Wilcox 1980, Soulé 1987, Lande 1988).

Resource availability also strongly influences species abundance and distribution (Gilbert 1980, Wheelwright 1983, Blake and Loiselle 1991, Sinclair and Norton-Griffiths 1995, Kinnaird et al. 1996), and fragmentation may influence distribution and availability of resources. The distribution and availability of fruit may be influenced by changes in soil moisture and plant demography that result from increased edge effects associated with fragmentation. Kapos et al. (1997) reported reduced soil moisture near the edges of forest fragments, a condition that has been shown to trigger flowering and fruiting of tropical trees (Foster 1982, Rathcke and Lacey 1985, Kinnaird 1992). Tropical trees tend to be long-lived and occur at low densities. Tree species in small fragments therefore may occur in non-viable numbers (Bierregaard et al. 1992) and may go extinct through stochastic processes (Lande 1988), thereby reducing fruit availability and diversity. Populations that persist in small fragments may suffer increased structural damage from high winds (Ferreira and Laurance 1997) and increased mortality (Nason et al. 1997), reducing population size and resulting in fewer fruiting trees. Invertebrate and vertebrate species that rely on fruit would be expected to decline as food supplies decline in fragments.

Although many researchers have investigated the effects of forest fragmentation on birds, most of these studies have come from the New World. Little is known about fragmentation effects for large, canopy-dwelling species (Galletti 1996), especially in the Asian tropics (Laurance and Bierregaard 1997). Additionally, few studies have examined the interaction between forest fragmentation and resource availability (Burke and Nol 1998), especially at the landscape level. The Indonesian island of Sumba provides a perfect setting to examine the influence of forest size and resource availability on a large frugivorous bird, Sumba Hornbill Aceros everetti.

Sumba is the third largest island $\left(10,854 \mathrm{~km}^{2}\right)$ in the Lesser Sunda Island chain and the southern-most island in Indonesia. Due to its restricted geographic range, small population size and extensive habitat loss, Sumba Hornbill is categorized as one of the most endangered hornbills in the world (Kemp 1995, O'Brien et al. 1998). Previous research has shown that Sumba Hornbills are rare in forest fragments under 1,000 ha in size but does not address whether rarity was a function of patch size, differences between patches in key resources, or a combination of these factors Since 1927, forest loss in Sumba has averaged 6, ooo ha/year, resulting in a loss of over 60\% of Sumba's forest cover (Marsden and Jones 1997). The remaining forests now exist as islands of habitat in a matrix of open wood- and grasslands. Closed-canopy forest (hereafter referred to as forest) now covers less than $11 \%$ of the island. What remains is fragmented into approximately 34 patches ranging from 16 to 42,500 ha (McKnight et al. 1994). Only five forest patches (15\%) exceed 2,500 ha in extent while almost $45 \%$ are below 500 ha in size (O'Brien et al. 1998).

We examine the influence of forest fragment size and food availability on Sumba Hornbill abundance and distribution. Because other species of Aceros hornbills are known to range over wide areas (Aceros undulatus: $28 \mathrm{~km}^{2}$, 
Poonswad and Tsuji 1994, Aceros cassidix: $55.8 \mathrm{~km}^{2}$, Suryadi et al. 1998), we predict that large patches are more likely to contain entire homeranges and therefore more hornbills than small patches. In addition, we expect hornbill numbers to fluctuate relative to fruit availability, especially fig species, as demonstrated by Kinnaird et al. (1996). If food supply drives hornbill abundance and small forests produce similar amounts of fruit per hectare to large forests, we would expect hornbill densities in large and small forests to be similar. Alternatively, if patch size, or some other non-food correlate such as number of nest trees, is critical then hornbill densities should be higher in large patches, regardless of variation in food supply.

\section{Methods}

\section{Study area}

We studied six forest fragments, dispersed across the Sumba landscape, from August 1998 through September 1999. Forest choice was random but constrained by accessibility. Forests varied in size, vegetation composition, structure, and degree of disturbance (Banilodu and Saka 1993). Three forests each were categorized as large $(\geq 1,000 \mathrm{ha})$ or small $(<1,000$ ha; Table 1$)$, according to the protocol used by O'Brien et al. (1998).

(1) Watumbelar forest, also referred to as the Langgaliru forest complex, was the largest sampled and ranges from 300 to $420 \mathrm{~m}$ above sea level (a.s.1.). It is a semi-deciduous monsoon vine forest, dominated by Palaquium obovatum (Sapotaceae) and Canarium oleosum (Burseraceae; Banilodu and Saka 1993).

(2) Manupeu forest lies directly west of the Langgaliru complex, ranges from 170 to $450 \mathrm{~m}$ a.s.l. and is one of the last lowland forest fragments on Sumba. A semi-deciduous monsoon vine forest, with some evergreen monsoon forest and open swamp areas, it is dominated by P. obovatum, Aglaia eusideroxylum (Meliaceae) and Myristica littoralis (Myristicaceae).

(3) Wanggameti forest, at 800-1,225 $\mathrm{m}$ a.s.l., is classified as lowland evergreen forest, with some elfin forest at higher altitudes. Its tree community is dominated by Podocarpus imbricatus (Podocarpaceae) and Planchonella nitida (Sapotaceae).

(4) Porunumbu forest is a typical semi-deciduous monsoon forest, with most forest occurring along ridge-tops at $500-700 \mathrm{~m}$ a.s.1. Its dominant tree

Table 1. Study sites on Sumba Island, Indonesia, and observation samples.

\begin{tabular}{lllll}
\hline Forest & Category/Size & Transect length $(\mathrm{km})$ & No. of plots & Province \\
\hline Wanggameti & Large/4, 480 ha & 6 & 7 & East \\
Watumbelar & Large/10,954 ha & 6 & 7 & East \\
Manupeu & Large/5,014 ha & 6 & 7 & West \\
Poronumbu & Small/732 ha & 4 & 5 & West \\
Waimangura & Small/200 ha & 2 & 3 & West \\
Cambaka & Small/100 ha & 2 & 3 & West \\
\hline
\end{tabular}


species include Palaquium obtusifolium (Sapotaceae), Aglaia sp. and Chisocheton sp. (Meliaceae; Banilodu and Saka 1993).

(5) Waimangura forest ranges between 300 and $400 \mathrm{~m}$ a.s.l. and is dominated by Ficus septica (Moraceae) and Melochia umbelata (Sterculiaceae) trees.

(6) Cambaka forest ranges between 150 and $250 \mathrm{~m}$ a.s.l. and is dominated by Chisocheton sp. and Tetrameles nudiflora (Datiscaceae) trees.

Mean annual rainfall on Sumba varies between 500 and 2,000 $\mathrm{mm}\left(\mathrm{O}^{\prime}\right.$ Brien et al. 1998). During our study, annual rainfall was greater in East Sumba $(2,300 \mathrm{~mm}$, Waingapu weather station) and rains were earlier than in West Sumba (1,100 mm, Waikabubak weather station). Temperature throughout the year varied between $20^{\circ} \mathrm{C}$ and $33^{\circ} \mathrm{C}$.

\section{Data collection and analysis}

Forests were surveyed monthly (with the exception of November 1998 and February 1999) to estimate hornbill densities, using a standard line transect method (Buckland et al. 1993). Each forest was sampled in proportion to its size (Table 1). Transects were walked twice each month between o6h30 and 11hoo, when hornbills were believed to be most active. If hornbills were seen during surveys, the following data were collected: angle from the trail to the birds, distance to the birds, cue for initial detection (seen, heard calling, or heard flying), number and sex of individuals, and activities (feeding, foraging or nesting).

Data were insufficient for the program DISTANCE to calculate monthly density (Buckland et al. 1993), so density estimates (birds $/ \mathrm{km}^{2}$ ) for each forest were made by multiplying the number of hornbills observed by the area sampled (Buckland et al. 1993). We used analysis of covariance to examine the effects of forest size, measures of fruit abundance and strangling fig density on monthly estimates of hornbill density (Sokal and Rohlf, 1981).

We established vegetation plots $(10 \times 50 \mathrm{~m})$ at $500 \mathrm{~m}$ intervals along half the distance of each line transect, e.g. plots were established along the first $3 \mathrm{~km}$ of a $6 \mathrm{~km}$ line transect (Table 1 ). In each plot, we tagged and collected the following data for all trees $>10 \mathrm{~cm}$ : scientific name, diameter at breast height $(\mathrm{DBH})$, estimated height (to the nearest $5 \mathrm{~m}$ ), presence of multiple stems (coppicing), and whether first major branching was above or below half of the tree's height (inversion point). The latter two measurements were used as indices of past disturbance, since multiple branching or bifurcation below the vertical midpoint of a tree may result if canopies are opened and light conditions increase. Canopy closure was estimated per plot, as the average percentage of the sky obscured by vegetation, in a field of view determined by a $10 \mathrm{~cm}$ length of 5 -cm-diameter PVC pipe ( $n=10$ random points). The number of cut trees and stumps within each plot was recorded as an indication of the level of disturbance. Two-sample $t$-tests were used to compare habitat structure and degree of disturbance between large and small forests (Sokal and Rohlf 1981).

\section{Phenological patterns}

Individual trees were tagged and examined monthly for the presence of flowers and fruits. Trees were classified according to the types of fruit they bore (husked 
fruit, fleshy fruit, beans or pods and figs). Monthly phenology scores of fruit cover and abundance for each forest patch were calculated only for "hornbill fruits" (strangling figs, fleshy and husked fruits). "Hornbill fruits" were categorized as those families and genera known to be consumed by other Aceros hornbills (Leighton 1982, Kemp 1995, Suryadi et al. 1994) or those whose seeds were found under active Sumba Hornbill nests (Suryadi in litt. 1996). All freestanding $(n=1)$ and strangling figs ( $n=6$ species) within $10 \mathrm{~m}$ of the first half of each transect were monitored because figs trees were rare within plots but are known to be important in the diet of Aceros hornbills (Leighton 1982, Kemp 1995, Kinnaird and O'Brien 1999, Suryadi et al. 1994). We estimated fruit availability in two different ways; first, as percentage canopy cover and, second, as the total number of fruits on a tree (crop size). To estimate percentage canopy cover, we scored the abundance of fruits and flowers on a scale of $\mathrm{O}-4$, where $\mathrm{O}=$ none of the canopy covered in flowers and fruits, $1=1-25 \%$ covered, $2=26-50 \%$ covered, $3=51-75 \%$ covered and $4=76-100 \%$ covered (sensu Struhsaker 1975). Average canopy cover by fruit was estimated as the midpoint of the fruit index for each tree and then averaged over all trees in the sample. Similar methods were used to calculate monthly average canopy cover by fruit type.

We derived estimates of fruit abundance by calculating the total monthly crop per plot and averaging across plots. Fruit abundance was divided into ripe and unripe fruits, and was calculated for all fruit types used by hornbills and for each category of fruit type. The percentage of ripe fruits was estimated to the nearest $5 \%$. To estimate the total number of fruits present on a tree (crop size), fruit numbers by order of magnitude were estimated (10s, 100s, 1,000s, 10,000s, etc.). Fruit abundance was then categorized at one of three levels $(1-3,4-6,7-9)$ and this was multiplied by the order of abundance i.e. category $1-3$ represents $10-30$ fruits, 100-300 fruits, or 1,000-3,000 fruits depending on the order of magnitude (Leighton 1993, Kinnaird et al. 1996).

We used the Kruskal-Wallis test to determine whether differences in phenological patterns existed between forests. First overall differences in the distribution of fruiting patterns between forests were tested and then pairwise comparisons were made to determine which forests were significantly different in phenological patterns.

\section{Results}

\section{Forest structure and phenology}

We sampled 32 vegetation plots within six forest patches, for a total of 0.55 ha in small forests and 1.05 ha in large forests. As expected, due to area alone, larger forests had more tree families and tree species than smaller forests, but species richness was similar between large and small forests as measured by Menhinisk's Index (Magurran 1988). Of 16 species, in five families, of important hornbill food trees known to occur on Sumba (Banilodu and Saka 1993; families Burseraceae, Gnetaceae, Lauraceae, Meliaceae and Myristicaceae), large forest plots contained 14 species in four families whereas small forest plots contained six species in two families. Large forest plots had significantly more trees per plot $(t=6.96, P<0.0001, \mathrm{df}=29.38)$, smaller mean $\mathrm{DBH}(t=3.33, P<0.002$, 
Table 2. Habitat configuration within the six study areas of fragmented forest on Sumba.

\begin{tabular}{|c|c|c|c|c|c|c|c|c|}
\hline Forest & Category & $\begin{array}{l}\text { Canopy } \\
\text { closure } \\
(\%)\end{array}$ & $\begin{array}{l}\text { Average } \\
\text { DBH } \\
(\mathrm{cm})\end{array}$ & $\begin{array}{l}\text { Basal area } \\
\left(\mathrm{cm}^{2} / \text { plot }\right)\end{array}$ & $\begin{array}{l}\text { Average } \\
\text { no. } \\
\text { stumps } \\
\text { /plot }\end{array}$ & $\begin{array}{l}\text { Average \% } \\
\text { coppiced } \\
\text { trees } \\
\text { /plot }\end{array}$ & $\begin{array}{l}\text { Average } \\
\text { no. } \\
\text { trees } \\
\text { /plot }\end{array}$ & $\begin{array}{l}\text { Average } \\
\% \text { trees } \\
\text { inverted } \\
\text { /plot }\end{array}$ \\
\hline Wanggameti & Large & 77.66 & 21.23 & 469.74 & 0.43 & 4.18 & 47.14 & 2.00 \\
\hline Watumbelar & Large & 80.61 & 22.99 & 560.50 & 1.57 & 0.39 & 32.14 & 0.29 \\
\hline Manupeu & Large & 62.84 & 26.92 & 862.07 & 1.00 & 0.00 & 26.43 & 1.86 \\
\hline Poronumbu & Small & $49 \cdot 44$ & $25 \cdot 34$ & 686.31 & 8.20 & 13.45 & 14.8 & 1.60 \\
\hline Waimangura & Small & 45.17 & 32.86 & 1194.91 & $3 \cdot 33$ & $5 \cdot 94$ & 19.67 & 6.33 \\
\hline Cambaka & Small & 50.96 & 36.47 & 1618.42 & 4.67 & 2.78 & 11.33 & 2.33 \\
\hline
\end{tabular}

$\mathrm{DBH}$, diameter at breast height.

$\mathrm{df}=30)$ and smaller basal area $(t=2.312, P<0.039, \mathrm{df}=12.45)$ than small forests (Table 2). Large forests had fewer signs of disturbance as measured by the number of cut stumps $(t=3.9, P<0.003, \mathrm{df}=10.79)$ and a lower degree of tree inversion $(t=3.096, P<0.004, \mathrm{df}=30$; Table 2$)$. Large forests also displayed a lower rate of coppicing $(1.5 \%$ vs $8.5 \%)$ but the difference was not significant $(P=0.07)$.

Phenological patterns varied among the six forest patches, due to variation in forest composition and differences in fruiting peaks (Figures 1 and 2). Large forests tended to fruit more in the rainy season months of October to March, whereas small forests exhibited more uniform patterns of fruiting. Fruiting in large forests was significantly less (Kruskal-Wallis test: $X^{2}=40.171, P<0.001$, $\mathrm{df}=1$ ) than in small forests. Percentage canopy cover by fruit in large forests never exceeded an average of $4 \%$ per tree whereas in small forests, average canopy cover ranged up to $12 \%$ per tree (Figures 1 and 2). Small forests also had larger fruit crops per plot than large forests (Kruskal-Wallis test: $X^{2}=30.227$, $P<0.001, \mathrm{df}=1)$. By removing particular fruit types from the data and reexamining fruiting patterns we found that free-standing figs contributed most to the overall fruiting patterns of the small Waimangura forest $\left(X^{2}=39.97\right.$, $P<0.001, \mathrm{df}=5)$ and fleshy fruits contributed significantly to the larger Wanggameti forest $\left(X^{2}=49.44, P<0.001, \mathrm{df}=5\right)$.

\section{Hornbill density}

We observed hornbills at least once in all forests, but they were seen more consistently in large forests (70\% vs $25 \%$ of monthly surveys; Figure 3 ). Among smaller forests, hornbills were present in Porunumbu during the breeding season (August-January), but disappeared during the non-breeding season. Hornbills were recorded only once in Cambaka and twice in Waimangura. In large forests, we observed hornbills in most months in Watumbelar and Manupeu, but only sporadically in Wanggameti. Mean individual density was $6 / \mathrm{km}^{2}$ in large forests and $2.4 / \mathrm{km}^{2}$ in small forests. Small forest estimates were based, however, on a few sightings at close distances and may therefore be overestimates.

Our data indicate that the overall fruit availability and fruit types in large and small forest fragments had no significant effect on hornbill density. However, an analysis of the effects of forest size, strangling fig density and fig crop on hornbill density indicated that hornbill densities were significantly higher in 

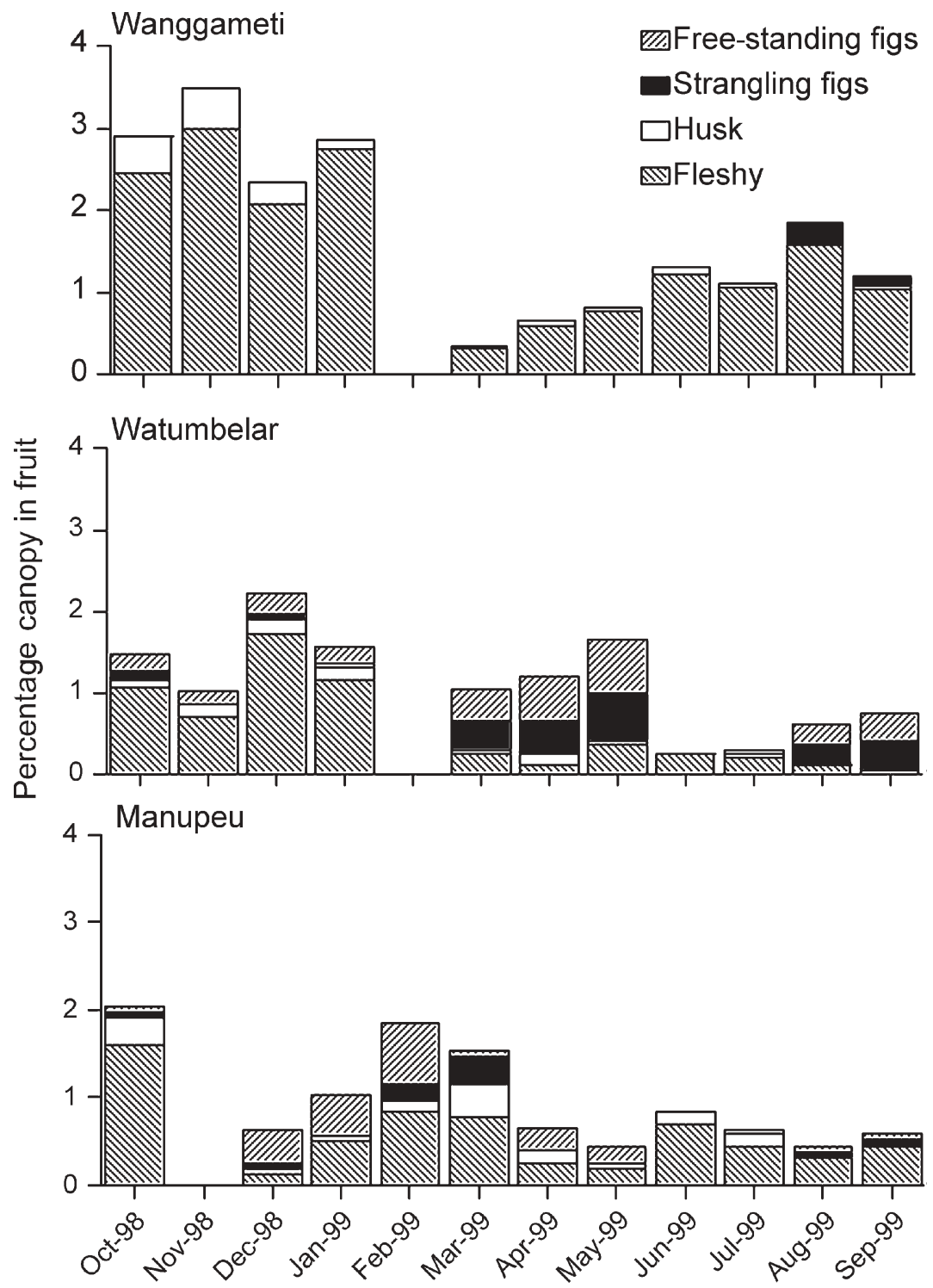

Figure 1. Monthly average percentage canopy cover for four fruit types in large forest patches on Sumba.

large forests and in forests with higher densities of strangling figs (Tables 3 and 4). If we ignore small patches, which include many months with no hornbills, and consider only large patches then we find a weak but significant positive correlation between hornbill density and abundance of ripe figs $\left(r_{S}=0.38\right.$, $P=0.027, n=33$ ). This suggests that hornbills may respond to fluctuations in fruit supply in the large patches and that the low density of hornbills in the large forest patch of Wanggametti may result from a low density of strangling figs (Table 3). 

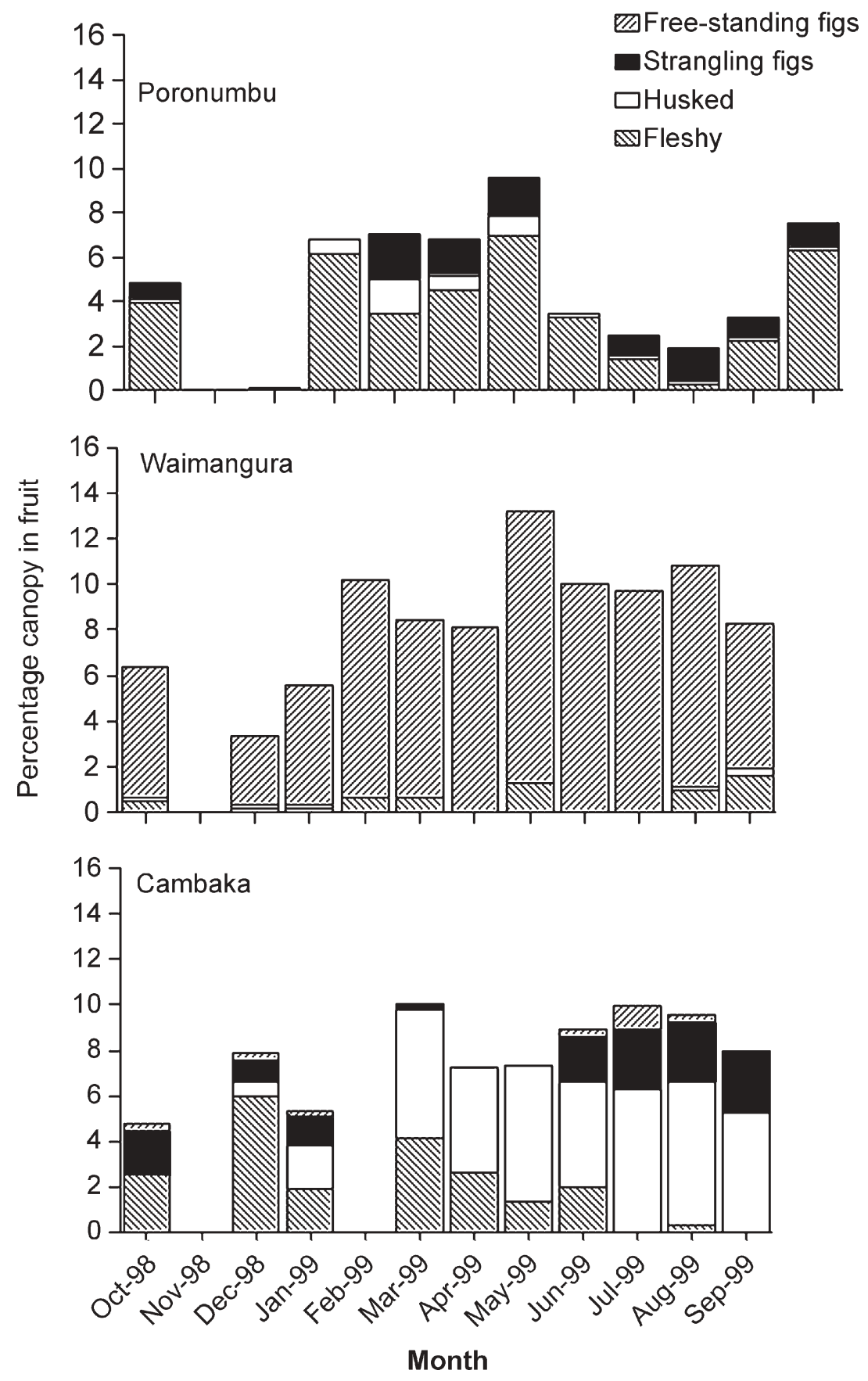

Figure 2. Monthly average percentage canopy cover for four fruit types in small forest patches on Sumba. 


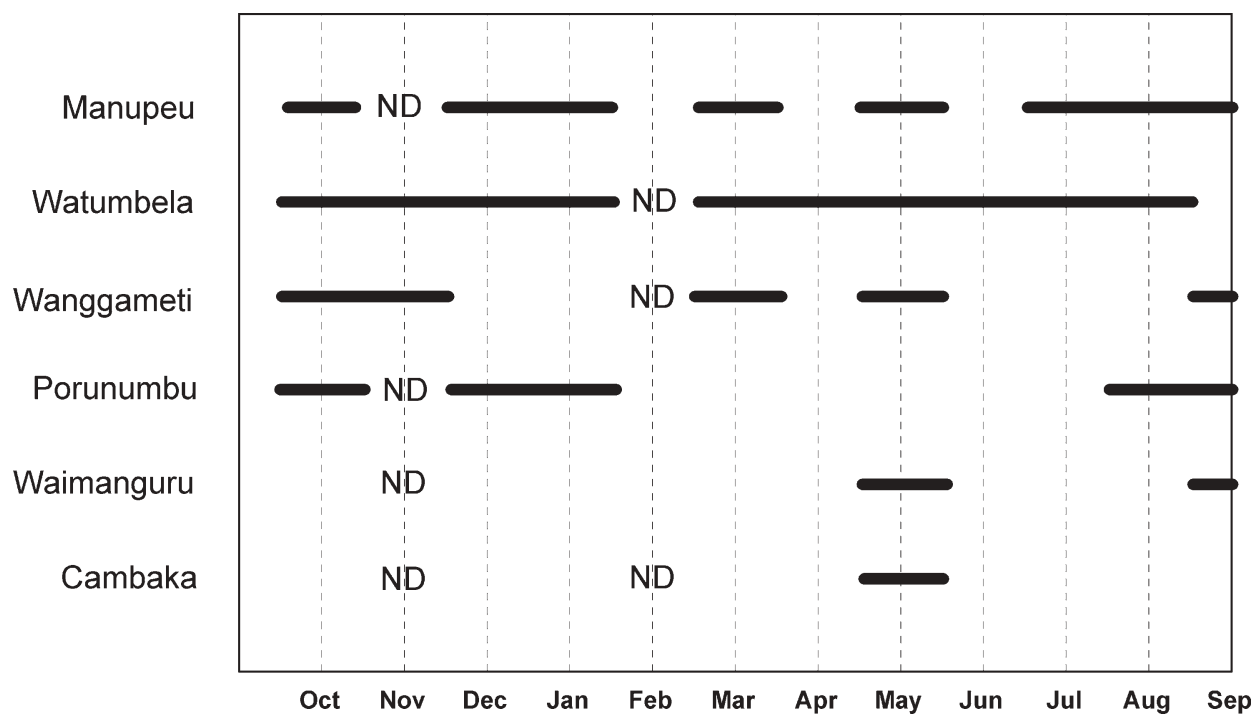

Figure 3. Presence of Sumba Hornbills on a monthly basis in large and small forests. ND indicates no data for the month.

Table 3. Estimated strangling fig and Sumba Hornbill densities (SD) in six forest fragments on Sumba.

\begin{tabular}{lll}
\hline Site & Strangling fig $/$ ha & Hornbill $/ \mathrm{km}^{2}$ \\
\hline Wanggameti & 0.17 & $0.95(1.54)$ \\
Watumbelar & 2.17 & $9.29(6.73)$ \\
Manupeu & 1.50 & $8.29(6.97)$ \\
Poronumbu & 1.75 & $3.22(4.33)$ \\
Waimangura & 0.00 & $1.95(4.63)$ \\
Cambaka & 3.00 & $2.15(6.77)$ \\
\hline
\end{tabular}

Table 4. Analysis of covariance relating monthly estimated hornbill density to forest size, strangling fig density and monthly fig crop on Sumba.

\begin{tabular}{lcccc}
\hline Variable & d.f. & MSE & $F$-test & $P>F$ \\
\hline Forest size & 1 & 218.1 & 6.63 & 0.012 \\
Density & 1 & 224.5 & 6.82 & 0.011 \\
Crop & 1 & 67.0 & 2.04 & 0.159 \\
Error & 62 & 32.9 & & \\
Total & 65 & & & \\
\hline
\end{tabular}

\section{Discussion}

Our data indicate that forest patch size may be more important in determining Sumba Hornbill abundance and distribution than overall food availability. In spite of differences in elevation, structure and levels of disturbance among forests, we were still able to detect differences in hornbill density related to forest size and resource abundance. As predicted, hornbills occurred in higher densities in large forests than small forests. These results strengthen the earlier 
findings of O'Brien et al. (1998) that relative abundance of Sumba Hornbills is higher in large forests across the species' range.

Although hornbill densities did fluctuate over time, their numbers were not related to our general measures of fruit availability. Kinnaird et al. (1996), working in a relatively large, contiguous forest, found that temporal fluctuations in densities of the related Sulawesi Red-knobbed Hornbill Aceros cassidix were influenced by the availability of fig fruits, and that the bird's spatial distribution was significantly affected by strangling fig density. Our data indicate that strangling fig densities may play a role in the distribution of Sumba Hornbills but that fig fruit availability influences Sumba Hornbill numbers only after forest size has been considered.

Forest size ultimately limits the size of strangling fig populations, and therefore the availability of fig fruit in a given forest. Fig populations in Sumba's smaller forest fragments may simply be too small to provide the continuous fruit production (Table 3, Figure 2) required for residency by a highly frugivorous hornbill. The lower diversity of fig species on Sumba compared with Sulawesi, Kalimantan and Sumatra (Banilodu and Saka 1993, Kinnaird et al. 1996, Kinnaird unpubl. data) has consequences for the overall availability of fig fruits. The asynchronous fruiting pattern within and among fig species (Janzen 1979, van Schaik 1986, Kinnaird et al. 1999) requires adequate population sizes of each species and adequate fig species diversity within a given area to ensure that at least one fig tree will be producing fruits at any given time within a hornbill's homerange.

A second factor that contributes to the low habitat quality of small forests is the under-representation or complete lack of other hornbill foods. Of the 16 nonfig species known to provide hornbill food, we recorded 14 species in our large forest plots but only six species in small forest plots. Although small forests had higher indices of fruit availability, the indices in Waimangura (Figure 1) were dominated by free-standing figs, primarily Ficus variegata, a species that fruits almost continuously but is never eaten by other Aceros hornbills and was never observed to be eaten by Sumba Hornbill. The families Meliaceae and Burseraceae, although present in the small forests, were under-represented. The small forests of Cambaka and Porunumbu had more preferred hornbill food species than Waimangura, but these trees occurred in small populations. Overall, small forests lacked species in the plant families Gnetaceae, Myristicaceae and Lauraceae, all of which were found in large forests.

We believe the lack of particular plant families in Sumba's small forests is a direct consequence of fragmentation. Tropical trees occur naturally at low densities (Hubbell and Foster 1986) and during the process of fragmentation, some rare species may be lost by chance alone (Lande 1988). As small forests become less attractive to large frugivores, they visit less and so deprive tree populations of important seed dispersers. Hornbills are almost exclusive dispersers of some genera in the Myristicaceae and Meliaceae families (Leighton 1982). Over time, a negative feedback may develop where lack of food trees discourages visits by frugivores and further reduces seed dispersal and regeneration.

Murcia (1996) suggests that remnants of less than 500 ha may not support viable populations of most tropical tree species, while obligate outcrossers are especially vulnerable at low population densities. Hall et al. (1996) demonstrated genetic erosion and lower rates of flowering and fruiting in small, fragmented populations of Pithecellobium elegans, a tropical tree in Costa Rica. However, our 
study showed higher levels of fruiting in small forests relative to large forest fragments, indicating that genetic variability may remain high among trees isolated in these small forests. We speculate that Sumba's forests are in a dynamic phase and that the full impact of fragmentation has not been expressed. Tropical trees generally live for more than 100 years (Kellman et al. 1996) and genetic deterioration may take several generations to become evident. The upward shift in average $\mathrm{DBH}$ and basal area of trees in small forests on Sumba suggests that little regeneration is occurring as the start of longer-term effects of fragmentation. Human disturbance may further limit regeneration and recruitment in small forests since they have a greater edge-to-interior ratio and are more accessible to local people. Small forests on Sumba had 6 times as many stumps per plot as large forests, a higher percentage of tree inversions and a higher percentage of coppicing.

Although Sumba Hornbills may reside in and prefer large forest fragments, small patches located within ranging distance of large patches may still be critical for their conservation. This study showed that small patches were used intermittently throughout the year and O'Brien et al. (1998) reported that almost half of the forests under 500 ha were used seasonally by hornbills when figs were in fruit. Small forest fragments may offer a safe haven for resting or roosting during dispersal and inter-forest movement, and they may provide an occasional essential fruit resource or nesting cavity. Alternatively, birds using small fragments may be subordinates displaced from better patches or hopeful colonists doomed to die.

We hypothesize that Sumba Hornbills may take advantage of a network of small and large patches to move through the surrounding agricultural matrix. Thus Sumba Hornbills may constitute one or more free-mixing subpopulations, with birds periodically disappearing from and recolonizing patches if the forest is not too small and isolated. More data are needed on hornbill ranging patterns, mortality rates and reproduction to test this hypothesis.

\section{Acknowledgements}

This project was funded by the Wildlife Conservation Society, conducted in collaboration with the Indonesian Directorate General Nature Protection and Conservation (PKA). We thank S. Metz for his generous support and E. Fox (WWF), N. Andalusi (PKA), and H. Embu and S. Rabenak (BirdLife International Sumba Project) for logistical support. L. Banilodu assisted in tree identification. We especially thank our field assistants Y. Kaha, A. Blegur and F. Bere Mau (PKA) and the people of Sumba, especially J. Kembi, F. and A. Yanggu, A. Lina, A. Tina, A. Mince and E. Ngongo, for their kindness and assistance.

\section{References}

Banilodu, L. and Saka, N. T. (1993) Descriptive analysis of Sumba forests. Widya Mandira Catholic University, Kupang, Timor, Indonesia: unpublished M.Sc. thesis.

Bierregaard, R. O. Jr, Lovejoy, T. E., Kapos, V., Augusto dos Santos A., and Hutchings, R. W. (1992) The biological dynamics of tropical rainforest fragments: a prospective comparison of fragments and continuous forest. BioScience 429: 859-866. 
Blake, J. G. and Loiselle, B. A. (1991) Variation in resource abundance affects capture rates of birds in three lowland habitats in Costa Rica. Auk 108: 114-130.

Brown, K. S. Jr and Hutchings, R. W. (1997) Disturbance, fragmentation, and the dynamics of diversity in Amazonian forest butterflies. Pp. 91-110 in W. F. Laurance and R. O. Bierregaard Jr, eds. Tropical forest remnants: ecology, management and conservation of fragmented communities. Chicago: University of Chicago Press.

Bruna, E. M. (1999) Seed germination in rainforest fragments. Nature 402: 139.

Buckland, S. T., Anderson, D. R., Burnham, K. P. and Laake, J. L. (1993) Distance sampling: estimating abundance of biological populations. London: Chapman and Hall.

Burke, D. M. and Nol, E. (1998) Influence of food abundance, nest-site habitat, and forest fragmentation on breeding ovenbirds. Auk 115: 96-104.

Decker, B. S. and Kinnaird, M. F. (1992) Tana river Red Colobus and Crested Mangabey: results of recent censuses. Amer. J. Primatol. 26: 47-52.

Ferreira, L. V. and Laurance, W. F. (1997) Effects of forest fragmentation on mortality and damage of selected trees in Central Amazonia. Conserv. Biol. 11: 797-801.

Foster, R. B. (1982) The seasonal rhythm of fruit fall on Barro Colorado Island. Pp. 151-172 in E. G. Leigh Jr, A. S. Rand and D. M. Windsor, eds. The ecology of tropical forests: seasonal rhythms and long-term change. Washington, DC: Smithsonian Institution Press.

Galletti, M. (1996) Fruits and frugivores in a Brazilian Atlantic Forest. University of Cambridge, U.K.: Unpublished Ph.D. thesis.

Gibbs, J. P. and Faaborg, J. (1990) Estimating the viability of ovenbird and Kentucky warbler populations in forest fragments. Conserv. Biol. 4: 193-196.

Gilbert, L. E. (1980) Food web organization and the conservation of neotropical diversity. Pp. 11-33 in M. E. Soulé and B. A. Wilcox, eds. Conservation biology: an evolutionaryecological perspective. Sunderland, MA: Sinauer Associates.

Hall, P., Walke, S. and Bawa, K. (1996) Effect of forest fragmentation on genetic diversity and mating system in a tropical tree, Pithecellobium elegans. Conserv. Biol. 10: 757-768.

Harris, L. D. (1984) The fragmented forest. Chicago: University of Chicago Press.

Hubbell, S. P. and Foster, R. B. (1986) Commonness and rarity in a Neotropical forest: Implications for tropical tree conservation. Pp. 205-231 in M. E. Soulé, ed. Conservation biology: the science of scarcity and diversity. Sunderland, MA: Sinauer Associates.

International Council for Bird Preservation (1992) Putting biodiversity on the map: priority areas for global conservation. Cambridge, U.K.: International Council for Bird Preservation.

Janzen, D. H. (1979) How to be a fig. Annu. Rev. Ecol. Syst. 10: 13-52.

Jones, M. J., Linsley M. D. and Marsden, S. J. (1995) Population sizes, status and habitat associations of the restricted range bird species of Sumba Indonesia. Bird Conserv. Intn. 5: 21-52.

Jules, E. S. (1998) Habitat fragmentation and demographic change for a common plant: Trillium in old-growth forest. Ecology 79: 1645-1656.

Kapos, V., Wandelli, E., Camargo, J. L. and Ganade, G. (1997) Edge-related changes in environment and plant responses due to forest fragmentation in Central Amazonia. Pp. 33-44 in W. F. Laurance and R. O. Bierregaard Jr, eds. Tropical forest remnants: ecology, management, and conservation of fragmented communities. Chicago: University of Chicago Press.

Karr, J. R. (1982) Population variability and extinction in the avifauna of a tropical land-bridge island. Ecology 63: 1975-1978.

Kellman, M., Tackaberry, R. and Meave, J. (1996) The consequences of prolonged fragmentation: lessons from tropical gallery forests. Pp. $37-58$ in R. Schelhas and R. Greenberg, eds. Forest patches in tropical landscapes. Washington, DC: Island Press.

Kemp, A. (1995) The hornbills. Oxford, U.K.: Oxford University Press.

Kinnaird, M. F. (1992) Phenology of flowering and fruiting of and east African riverine forest ecosystem. Biotropica 24: 187-194. 
Kinnaird, M. F. and O'Brien, T. G. (1999) Breeding ecology of the Sulawesi Red-knobbed Hornbill, Aceros cassidix. Ibis 141: 60-69.

Kinnaird, M. F., O’Brien T. G. and Suryadi, S. (1996) Population fluctuation in Sulawesi Red-Knobbed Hornbills: tracking figs in space and time. Auk 113: 431-440.

Kinnaird, M. F., O'Brien, T. G. and Suryadi, S. (1999) The importance of figs to Sulawesi's imperiled wildlife. Trop. Biodiv. 6: 5-18.

Klein, B. C. (1989) The effects of forest fragmentation on dung and carrion beetle (Scarabaeinae) communities in central Amazonia. Ecology 70: 1715-1725.

Lande, R. (1988) Genetics and demography in biological conservation. Science 241: 1455-1460.

Laurance, W. F. (1989) Ecological impacts of tropical forest fragmentation on nonflying mammals and their habitats. University of California, Berkeley: unpublished Ph.D. dissertation.

Laurance, W. F. and Bierregaard, R. O. Jr (1997) Tropical forest remnants: ecology, management, and conservation of fragmented communities. Chicago: University of Chicago Press.

Laurance, W. F., Ferreira, L. V., Rankin-De Merona, J. M., Laurance, S. G., Hutchings, R. W. and Lovejoy, T. E. (1998) Effects of forest fragmentation on recruitment patterns in Amazonian tree communities. Conserv. Biol. 12: 460-464.

Leighton, M. (1982) Fruit resources and patterns of feeding, spacing and grouping among sympatric Bornean hornbills (Bucerotidae). University of California, Davis: unpublished Ph.D. dissertation.

Leighton, M. (1993) Modeling dietary selectivity by Bornean orangutans: evidence for integration of multiple criteria in fruit selection. Intn. J. Primatol. 14: 257-313.

Lynam, A. J. (1997) Rapid decline of small mammals diversity in monsoon evergreen forest fragments in Thailand. Pp. 222-240 in W. F. Laurance and R. O. Bierregaard $\mathrm{Jr}$, eds. Tropical forest remnants: ecology, management, and conservation of fragmented communities. Chicago: University of Chicago Press.

Magurran, A. E. (1988) Ecological diversity and its measurement. Princeton, NJ: Princeton University Press.

Malcolm, J. R. (1994) Edge effects in Central Amazonian forest fragments. Ecology 75: 2438-2445.

Malvido, B. J. (1998) Impact of forest fragmentation on seedling abundance in a tropical rain forest. Conserv. Biol. 12: 380-389.

Marsden, S. J. and Jones, M.J. (1997) The nesting requirements of the parrots and hornbill of Sumba, Indonesia. Biol. Conserv. 82: 279-287.

McKnight, A., Jepson, P. and Rharjaningtrah, W. (1994) Figures of forest cover on Sumba. Bogor, Indonesia: unpublished Technical Report, BirdLife International Indonesia Programme.

Menon, S. and Poirier, F. P. (1996) Lion-tailed macaques (Macaca silenus) in a disturbed forest fragment; activity patterns and time budget. Intn. J. Primatol. 17: 969-985.

Murcia, C. (1996) Forest fragmentation and the pollination of Neotropical plants. Pp. 19-36 in J. Schelhas and R. Greenberg, eds. Forest patches in tropical landscapes. Washington, DC: Island Press.

Nason, J. D., Adrich, P. R. and Hamrick, J. L. (1997) Dispersal and the dynamic of genetic structure in fragmented tropical tree populations. Pp. 304-320 in W. F. Laurance and R. O. Bierregaard Jr, eds. Tropical forest remnants: ecology, management, and conservation of fragmented communities. Chicago: University of Chicago Press.

Newmark, W. D. (1987) A land-bridge island perspective on mammalian extinctions in western North American parks. Nature 325: 430-432.

O'Brien, T. G., Kinnaird, M. F, Jepson, P., and Setiawan, I. (1998) Effect of forest size and structure on the distribution of Sumba Wreathed Hornbills Aceros everetii. Pp. 209-218 in P. Poonswaad, ed. The Asian hornbill: ecology and conservation. Bangkok: Thai studies in biodiversity No. 2 . 
Pickett, S. T. A. and White, P. S. (1985) The Ecology of Natural Disturbance and Patch Dynamics. Orlando, FL: Academic Press.

Poonswaad, P. and Tsuji, A. (1994) Range of males of the Great Hornbill Buceros bicornis, Brown Hornbill Ptilolaemus tickelli, and Wreathed Hornbill Rhyticeros undulatus in Khao Yai National Park, Thailand. Ibis 136: 79-86.

Rathcke, B. and Lacey, E. P. (1985) Phenological patterns of terrestrial plants. Annu. Rev. Ecol. Syst. 16: 179-214.

Restrepo, C., Renfifo, L. M. and Marples, P. (1997) Frugivoruos bird in fragmented neotropical montane forests: landscape pattern and body mass distribution. Pp. 171-189 in W. F. Laurance and R. O. Bierregaard Jr, eds. Tropical forest remnants: ecology, management, and conservation of fragmented communities. Chicago: University of Chicago Press.

Robinson, S.K. (1998) Another threat posed by forest fragmentation: reduced food supply. Auk 115: 1-3.

Rylands, A. B. and Keuroghlian, A. (1988) Primate populations in continuous forest and forest fragments in central Amazonia. Acta Amazonica 18: 291-307.

Sieving, K. E. and Karr, J. R. (1997) Avian extinction and persistence mechanisms in lowland Panama. Pp. 156-170 in W. F. Laurance and R. O. Bierregaard Jr, eds. Tropical forest remnants: ecology, management and conservation of fragmented communities. Chicago: University of Chicago Press.

Sinclair, A. R. E. and Norton-Griffiths, M. (1995) Serengeti: dynamics of an ecosystem. Chicago: University of Chicago Press.

Sokal, R. R. and Rohlf, F. J. (1981) Biometry, 2nd edition. New York: W.H. Freeman.

Soulé, M. E. (1987) Viable populations for conservation. Cambridge, U.K.: Cambridge University Press.

Soulé, M. E. and Wilcox, B. A. (1980) Conservation biology: an evolutionary-ecological perspective. Sunderland, MA: Sinauer Associates.

Struhsaker, T. T. (1975) The Red Colobus Monkey. Chicago: University of Chicago Press.

Suryadi, S., Kinnaird, M. F., O’Brien, T. G., Supriatna, J. and Somadikarta, S. (1994) Food preferences of the Red-knobbed Hornbill during the non-breeding season. Trop. Biodiv. 2: $377-384$.

Suryadi, S., Kinnaird, M. F. and O'Brien, T. G. (1998) Home ranges and daily movements of the Sulawesi Red-knobbed Hornbill Aceros cassidix during the non-breeding season. Pp. 159-170 in P. Poonswaad, ed. The Asian hornbill: ecology and conservation. Bangkok: Thai studies in biodiversity No. 2.

Terborgh, J. (1990) Where have all the birds gone? Essay on the biology and conservation of birds that migrate to the American tropics. Princeton, NJ: Princeton University Press.

Terborgh, J. W. and Winter, B. (1980) Some causes of extinction. Pp. 119-133 in M. E. Soulé and B. A. Wilcox, eds. Conservation biology: an evolutionary-ecological perspective. Sunderland, MA: Sinauer Associates.

Tocher, M. D., Gascon, C. and Zimmerman, B. (1997) Fragmentation effects on a centralAmazonian frog community: a ten-year study. Pp. 124-137 in W. F. Laurance and R. O. Bierregaard Jr, eds. Tropical forest: ecology, management and conservation of fragmented communities. Chicago: University of Chicago Press.

Turner, I. M., Chua, K. S., Ong, J. S. Y., Soong, B. C. and Tan, H. T. W. (1996) A century of plant species loss from an isolated fragment of lowland tropical rain forest. Conserv. Biol. 10: 1220-1244.

van Schaik, C. P. (1986) Phenological changes in a Sumatran rain forest. J. Trop. Ecol. 2: 327-347.

Wheelwright, N. T. (1983) Fruits and the ecology of Resplendent Quetzal. Auk 100: 286-301.

Wilcove, D. S. (1985) Nest predation in forest tracts and the decline of migratory songbirds. Ecology 66: 1211-1214. 
Wilcove, D. S., McLelland, C. H. and Dobson, A. P. (1986) Habitat fragmentation in the temperate zone. Pp. 237-256 in M. E. Soulé, ed. Conservation biology: the science of scarcity and diversity. Sunderland, MA: Sinauer Associates.

Wong, T. C. M., Sodhi, J. S. and Turner, I. M. (1998) Artificial nest and seed predation experiments in tropical lowland rainforest remnants of Singapore. Biol. Conserv. 85: 97-104.

ARNOLD F. SITOMPUL ${ }^{1,2}$, MARGARET F. KINNAIRD ${ }^{1,3}$ and TIMOTHY G. O'BRIEN ${ }^{1,3}$

${ }^{1}$ Wildlife Conservation Society - Indonesia Program, P.O. Box 311, Jl. Pangrango No. 8, Bogor 16003, Indonesia

${ }^{2}$ Warnell School of Forest Resources, University of Georgia, Athens, Georgia, USA

${ }^{3}$ Wildlife Conservation Society - Asia Program, 2300 Southern Blvd., Bronx, NY 10460, USA (e-mail:afs679o@owl.forestry.uga.edu) 